\title{
Influence of geochemical processes on hydrochemistry and irrigation suitability of groundwater in part of semi-arid Deccan Plateau, India
}

\author{
Duraisamy Vasu ${ }^{1} \cdot$ Surendra Kumar $\operatorname{Singh}^{1} \cdot \operatorname{Pramod}_{\text {Tiwary }}{ }^{1} \cdot$ Nisha Sahu $^{1} \cdot$ \\ Sanjay Kumar Ray $^{2} \cdot$ Pravin Butte $^{1} \cdot$ Veppangadu Perumal Duraisami $^{3}$
}

Received: 2 June 2016/ Accepted: 11 January 2017/Published online: 13 February 2017

(c) The Author(s) 2017. This article is published with open access at Springerlink.com

\begin{abstract}
Major ion geochemistry was used to characterise the chemical composition of groundwater in part of semiarid Deccan plateau region to understand the geochemical evolution and to evaluate the groundwater quality for irrigation. The study area comprises peninsular gneissic complex of Archean age, younger granites and basaltic alluvium. Forty-nine georeferenced groundwater samples were collected and analysed for major ions. The ionic sequence based on relative proportions was $\mathrm{Na}^{+}>\mathrm{Mg}^{2+}>\mathrm{Ca}^{2+}>$ $\mathrm{SO}_{4}{ }^{2-}>\mathrm{HCO}_{3}{ }^{-}>\mathrm{Cl}^{-}>\mathrm{CO}_{3}{ }^{2-}>\mathrm{BO}_{3}{ }^{3-}>\mathrm{K}^{+}$. High $\mathrm{Na}^{+}, \mathrm{Mg}^{2+}$ and $\mathrm{Ca}^{2+}$ were generally associated with basaltic alluvial formation, whereas $\mathrm{pH}$, electrical conductivity (EC) and total dissolved salts (TDS) were found to be higher in granitic formations. High standard deviation for EC, TDS, $\mathrm{Na}^{+}, \mathrm{Ca}^{2+}$ and $\mathrm{Mg}^{2+}$ indicated the dispersion of ionic concentration throughout the study area. Four major hydrochemical facies identified were $\mathrm{Na}-\mathrm{Mg}-\mathrm{HCO}_{3}$ type; $\mathrm{Mg}-\mathrm{Na}-$ $\mathrm{HCO}_{3}$ type; $\mathrm{Na}-\mathrm{Mg}-\mathrm{Ca}-\mathrm{SO}_{4}$ and $\mathrm{Mg}-\mathrm{Na}-\mathrm{Ca}-\mathrm{SO}_{4}$ type. The graphical plots indicated that the groundwater chemistry was influenced by rock-water interaction, silicate weathering and reverse ion exchange. Sodium-dominated waters might have impeded the hydraulic properties of soils as a result of long-term irrigation.
\end{abstract}

Duraisamy Vasu

d.plantdoctor@gmail.com

1 ICAR-National Bureau of Soil Survey and Land Use Planning, Amravati Road, Nagpur 440033, Maharashtra, India

2 Regional Centre, ICAR-National Bureau of Soil Survey and Land Use Planning, Jorhat 785 004, Assam, India

3 Directorate of Natural Resource Management, Tamil Nadu Agricultural University, Coimbatore 641003, Tamil Nadu, India
Keywords Hydrogeochemistry · Groundwater quality · Deccan plateau $\cdot$ Silicate weathering $\cdot$ Rock-water interaction

\section{Introduction}

Agriculture sector consumes about $70 \%$ of available groundwater in India and out of total irrigated area of $64.05 \mathrm{~m}$ ha, $66 \%$ (42.5 m ha) is irrigated by groundwater. The depth of groundwater table decreased over the past few decades due to poor recharge of the groundwater aquifers caused by gradual decrease in annual rainfall (Singh et al. 2006). The rate of decline in groundwater depth is so alarming that $34 \%$ of the wells studied showed more than $4 \mathrm{~m}$ decrease in depth of water level (CGWB 2015). The Deccan plateau region covers most of the central and southern parts of the country with an area of 0.42 million $\mathrm{km}^{2}$ (Vasu et al. 2016). It is characterised by semi-arid climate coupled with high mean annual evapotranspiration of $1800 \mathrm{~mm}$ (Perrin et al. 2012) than precipitation (700-900 mm). The reduction $(7-20 \%)$ in seasonal monsoon (IMD 2015) along with depleting groundwater in the past two decades has made agriculture a challenging task. Thus, vagaries of climate change have pronounced impacts on agriculture, livelihood and economy in this region. Groundwater is the major source for irrigation in Deccan plateau and its quality depends on its chemical composition. The hydrochemistry of groundwater is influenced by aquifer characteristics and the strata over which they flow (Rengaraj 1996). The factors that control the dissolved minerals in groundwater are types of minerals that make up the aquifer, length of time that the water is in contact with the minerals and the chemical state of the groundwater. 
Different rocks (e.g. sandstone, limestone and basalt) with varying composition in contact with groundwater will result in groundwater varying in ionic compositions. Hydrogeochemical study of groundwater helps to determine the origin of chemical constituents (Zaporozec 1972) and to identify the factors governing it, contribution made by each factor and type of the geochemical reactions that are taking place within an aquifer system. Identification of geochemical processes helps to understand the quality of water and assist in planning irrigation management.

Many researchers around the world (Moller et al. 2007; Belkhiri et al. 2010; Glover et al. 2012) and in India (Srinivas et al. 2013; Selvakumar et al. 2014; Nageswara Rao et al. 2015) showed the role of hydrogeochemistry in groundwater quality. Earlier investigations indicated that hydrochemistry of groundwater is controlled by geochemical processes in semi-arid regions of India (Subramani et al. 2010). Processes such as evaporation, oxidation/ reduction, ion exchange, minerals weathering, precipitation of secondary minerals and mixing of waters control the chemical composition of groundwater and temporal changes in it (Kumar et al. 2009). Telangana is by far the state in the Deccan plateau region receiving very less average annual rainfall $(450-700 \mathrm{~mm})$ which is unevenly distributed and the agriculture sector registered a mixed growth rate varying from 25.2 to $-10.0 \%$ during the past decade due to frequent droughts. Hence, there is sharp rise in area under irrigation through tube wells and out of 3 million ha irrigated area, about 3/4th area is irrigated by groundwater. This has led to over-exploitation of groundwater from deep bore-wells (Chandra et al. 2012). Studies on groundwater quality for domestic and irrigation purposes in this region (Pophare and Dewalkar 2007; Satyanarayanan et al. 2007) and in similar kind of geological formations around the world (Belkhiri et al. 2010; Aghazadeh and Mogaddam 2011) indicated the influence of geochemical processes on ionic composition of groundwater.

Recently, several graphical methods and different indices were used for evaluating groundwater quality (Elango et al. 2003; Subbarao 2006). Reddy and Kumar (2010) found that groundwater in Anantapur region is $\mathrm{Ca}^{2+}-\mathrm{Mg}^{2+}-\mathrm{Cl}^{-}-\mathrm{HCO}_{3}{ }^{-}$type and their composition was influenced by ion exchange and dissolution processes. Rajesh et al. (2012) found that the cationic and anionic concentrations were in the order of $\mathrm{Na}^{+}>\mathrm{Ca}^{2+}>$ $\mathrm{Mg}^{2+}>\mathrm{K}^{+}$and $\mathrm{HCO}_{3}{ }^{-}>\mathrm{SO}_{4}{ }^{2-}>\mathrm{Cl}^{-}>\mathrm{CO}_{3}{ }^{2-}$, respectively, in groundwater of Nalgonda district and concluded that ion exchange process controls the concentration of calcium, magnesium and sodium. Studies in the watersheds of Mahabubnagar district showed that waters are sodium bicarbonate, sodium chloride, mixed cationic-mixed anionic, mixed cationic Na-dominating bicarbonate and are medium salinity low-sodium (C2S1), high salinity low-sodium (C3S1) and high salinity medium-sodium (C3S2) for irrigation (Raju and Goud 1990; Reddy 2013). Moreover, the groundwater of Peninsular gneissic complex aquifers in the Deccan plateau region are suspected to have high salt content and to be poor in quality (Suresh and Kottureshwara 2009; Kumar et al. 2009; Reddy and Patode 2013; Yadagiri et al. 2015). Thus, groundwater quality has become the topic of debate among researchers and groundwater authorities and its allocation to different sectors viz., agriculture, industry and drinking water use has become a challenging task for the policy makers. Since agriculture is the mainstay of rural people of Telangana, an attempt has been made in the present study to assess the groundwater quality in Thimmajipet mandal, Mahabubnagar district in Telangana, India, with the following objectives: (i) to determine the major ion chemistry of groundwater, (ii) to identify the hydrogeochemical processes responsible for the groundwater quality and (iii) to assess the groundwater suitability for irrigation purpose.

\section{Materials and methods}

\section{Study area}

Thimmajipet mandal is situated at a distance of $100 \mathrm{~km}$ from Hyderabad, India, and lies between $16^{\circ} 35^{\prime}$ to $16^{\circ} 44^{\prime} \mathrm{N}$ latitude and $78^{\circ} 07^{\prime}$ to $78^{\circ} 18^{\prime} \mathrm{E}$ longitude with total geographical area of $200.90 \mathrm{~km}^{2}$ (Fig. 1). The topography of the area comprises an undulating terrain with a maximum elevation of $662 \mathrm{~m}$ on south-western side and minimum elevation of $434 \mathrm{~m}$ on the northern side. In general, the ground surface slopes towards north-eastern direction with intermittent hillocks. The study area falls under southern Telangana agro-climatic zone and is characterised by ustic soil moisture and hyperthermic soil temperature regimes (Soil Survey Staff 2003). The average annual rainfall is 450-550 mm which occurs mostly during southwest monsoon (July-September). Major crops grown are cotton (Gossypium hirsutum), maize (Zea mays), pigeon pea (Cajanus cajan), rice (Oryza sativa) and sorghum (Sorghum bicolor).

\section{Geology and hydrogeology}

In the arid and semi-arid regions of southern India, Peninsular Gneissic Complex (PGC) type aquifers are dominant (CGWB 2012). They are formed on the base of migmatites, granite gneiss and granites ranging in composition from granodiorite to tonalite and intruded younger dolerites. These abundant granitoid rocks are of calc- 


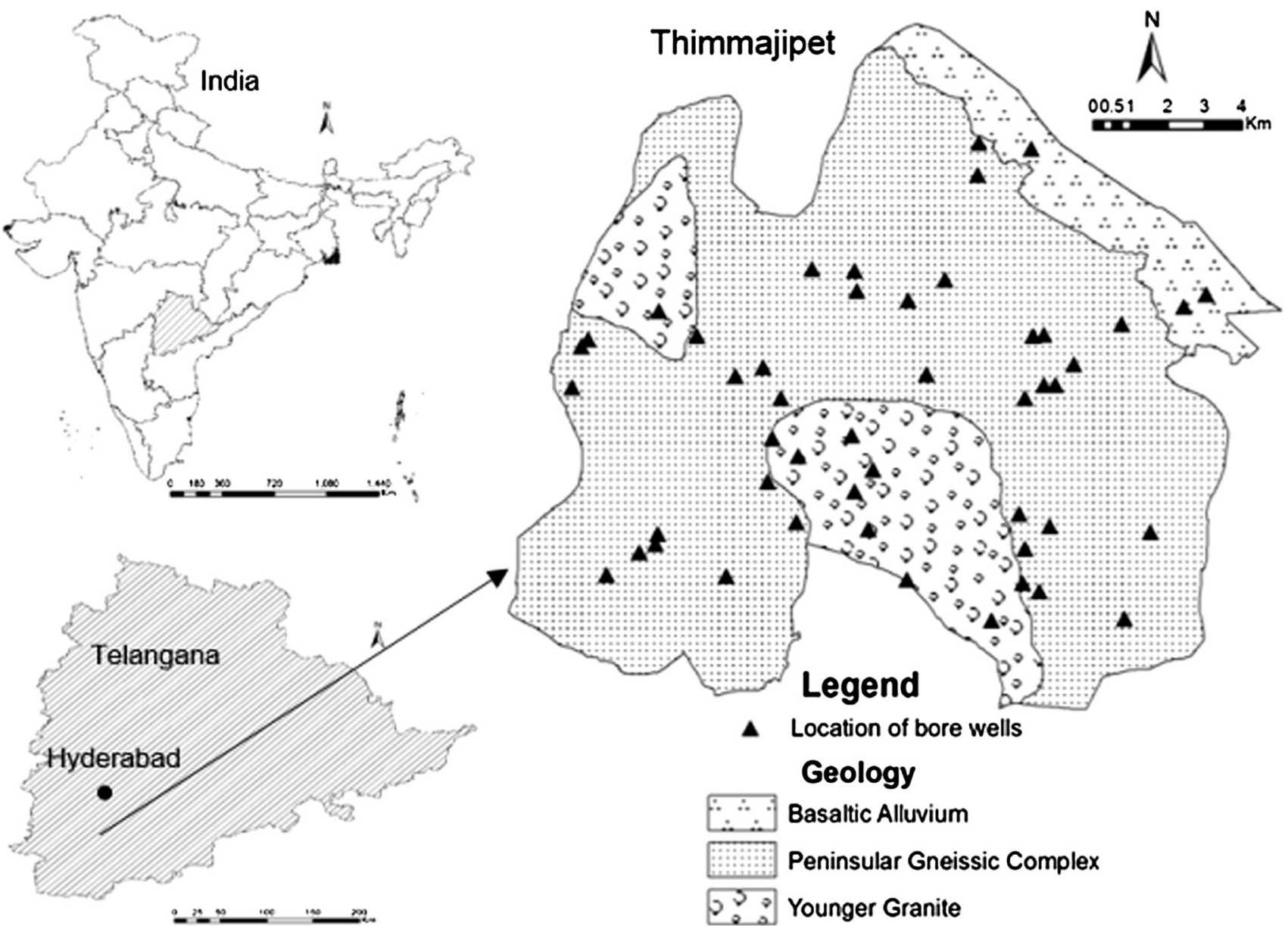

Fig. 1 Location of the study area and sampling locations in different geological formations

alkaline nature (Balakrishnan et al. 1990; 1999; Krogstad et al. 1991). Sanukitioids, a high Mg, high Ni granitoids are also present and monoclinic series of amphiboles tremolite, actinolite comprising $\mathrm{Ca}, \mathrm{Mg}$ and halogens $(\mathrm{F}, \mathrm{Cl})$ occur as intrusive with the PGCs. Being of Archean age, the south Indian Peninsula has long been exposed to weathering agents and the rocks have undergone different degrees of secondary decomposition resulting in layers of weathered, semi-weathered zones, as well as massive fractured rocks and fissures, cracks and joints. The fracture zones are hydraulically connected with the overlying weathered and saturated residuum (CGWB 2009) and upon weathering they result in salts rich in calcium, magnesium, sodium, fluoride and chlorides. Hydrogeologically, the subsurface of this region can be characterised by three distinct layer systems viz., soil zone, weathered zone and massive rock layers zone. Thickness of the soil zone varied from 0.16 to $3 \mathrm{~m}$ and is comparatively thicker in the northern, northwestern and north-eastern boundaries of the study area due to basaltic alluvial depositions. The granite-gneiss lacks primary porosity and occurrence of groundwater is limited to secondary porosity developed by weathering and fracturing (CGWB 1975). The diameter of waterwells is $15-20 \mathrm{~cm}$ and their depth varied from 40 to $160 \mathrm{~m}$. The thickness of weathered zone ranged from 3 to $15 \mathrm{~m}$ with granular fractured zones occuring at $20-60 \mathrm{~m}$ below ground level. The yield of water wells ranged from 0.11 to $0.18 \mathrm{~m}^{3}$ per minute.

The study area forms a part of the stable Dharwar Craton of south Indian shield. It consists of exposed rocks of Peninsular Gneissic Complex (Archaean to Paleoproterozoic age), Dharwar Supergroup, Cuddapah Supergroup, Kurnool and Bhima Groups and also alluvium of basaltic Deccan Traps (CGWB 2013). Three geological formations comprise the study area: (1) Peninsular Gneissic Complex, (2) Basaltic Alluvium and (3) Younger Granite. The Peninsular gneissic complex (PGC), which covers most of the area, comprises granites, gneisses and migmatites with undigested patches of older metamorphic rocks. The rocks of PGC and Dharwar Supergroup are intruded by younger granitoids of tonalite-trondhjermite-grandodiortite composition (Sharma 2009). These rocks are generally medium- to coarse-grained and are foliated due to the alternate arrangements of minerals and the dimensional orientation 


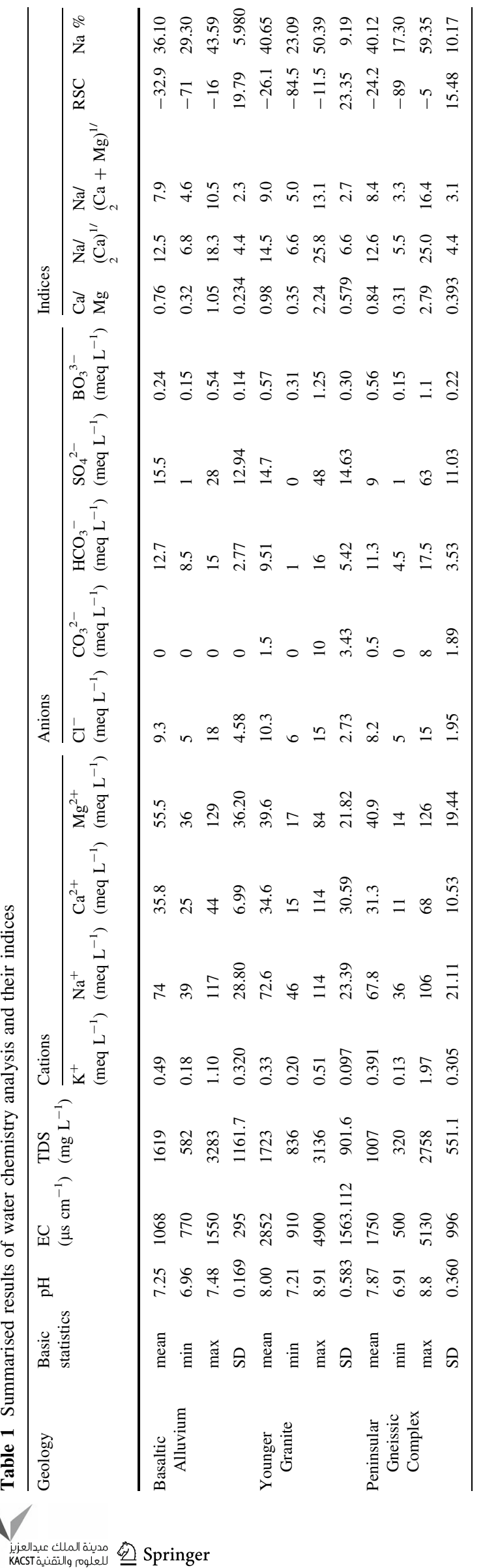

of light minerals such as quartz and feldspar (Balakrishnan et al. 1990).

\section{Sample collection and analysis}

Forty-nine georeferenced (GPS location with latitude and longitude) groundwater samples, i.e., 34, 10 and 5 from PGC, younger granite and basaltic alluvium, respectively, were collected during February (2015) from water wells in pre-cleaned $500 \mathrm{ml}$ plastic bottles after pumping water for 10-15 min to minimise errors due to oxidising and carbonating agents. All the sampling bottles were rinsed thoroughly two times using the well water before sampling. The collected samples were tightly packed to protect from atmospheric $\mathrm{CO}_{2}$ and transported to laboratory and stored in a refrigerator at $4^{\circ} \mathrm{C}$ before analysis. The extra-pure analytical-grade reagents and chemical standards (Merck Grade) were used for the groundwater quality analysis by adopting standard procedures suggested by American Public Health Association (APHA 2005). The samples were analysed for $\mathrm{pH}$ and electrical conductivity (EC) using digital $\mathrm{pH}$ and EC meter (ELICO make). $\mathrm{Ca}^{2+}$ and $\mathrm{Mg}^{2+}$ were measured in ICP-AES. $\mathrm{Na}^{+}$and $\mathrm{K}^{+}$were determined by flame photometer. Carbonate $\left(\mathrm{CO}_{3}{ }^{2-}\right)$ and bicarbonate $\left(\mathrm{HCO}_{3}{ }^{-}\right)$were measured using acid titration method. Chloride $\left(\mathrm{Cl}^{-}\right)$was measured by $\mathrm{AgNO}_{3}$ titration method. Sulphate $\left(\mathrm{SO}_{4}{ }^{2-}\right)$ was measured by $\mathrm{BaCl}_{2}$ method using UV spectrophotometer (Shimadzu UV-2600, A116652). Total dissolved solids (TDS) were computed by the method of Hem (1991). Blank, standards and triplicate samples were run during the analysis of samples to check the accuracy and reliability of analysis methods. The ion charge balance was less than $\pm 5 \%$ for all the samples.

\section{Statistical analysis}

The Statistical package for social sciences (SPSS) version 20 was used to carry out all the statistical analysis. In the factor analysis, 'principal components' was selected as the solution method, whereas the varimax rotation was used to maximise the differences among selected factors to facilitate interpretation of analysis results. Important indicators of water quality for irrigation were derived using the guidelines given by United States Salinity Laboratory (USSL 1954) and FAO (Ayers and Westcot 1985). Parameters such as $\mathrm{pH}$, electrical conductivity, soluble sodium percentage (Todd 1995), residual sodium carbonate (Gupta and Gupta 1987), potential salinity (Hammet 1992), magnesium hazard (Raghunath 1987), Kelly's ratio (Kelly 1963) and permeability index (Doneen 1964) were used to assess the suitability of water for irrigation. 


\section{Results and discussion}

\section{Major ion chemistry and spatial distribution}

The variation in the concentration levels of different hydrogeochemical constituents dissolved in water determines its usefulness for domestic, industrial and agricultural purposes (Obiefuna and Sheriff 2011). The results showed that $\mathrm{pH}$ varied from 6.91 to 8.91 , the mean $\mathrm{pH}$ value (8.0) indicating marginal alkalinity of the groundwater (Table 1). Electrical conductivity varied from 500 to $5130 \mu \mathrm{S} \mathrm{cm}^{-1}$ and total dissolved salts (TDS) varied from 320 to $3283 \mathrm{mg} \mathrm{L}^{-1}$. Electrical conductivity was found be higher in the southern and central part of the study area and it decreased towards north and north eastern direction (Fig. 2). Among the cations $\mathrm{Ca}^{2+}$ varied from 11 to 114 meq $\mathrm{L}^{-1} ; \mathrm{Mg}^{2+}$ from 14 to $129 \mathrm{meq} \mathrm{L}^{-1} ; \mathrm{K}^{+}$from 0.13 to $1.97 \mathrm{meq} \mathrm{L}^{-1}$ and $\mathrm{Na}^{+}$from 35.65 to $117 \mathrm{meq} \mathrm{L}{ }^{-1}$. Among the anions $\mathrm{Cl}^{-}$varied from 5 to $18 \mathrm{meq} \mathrm{L}^{-1} ; \mathrm{CO}_{3}{ }^{2-}$ from 0 and $10 \mathrm{meq} \mathrm{L}^{-1}$ and $88 \%$ of the samples were found to be without $\mathrm{CO}_{3}{ }^{2-}$ content. $\mathrm{HCO}_{3}{ }^{-}$varied from 0.3 to $17.5 \mathrm{meq}{ }^{-1} ; \mathrm{SO}_{4}{ }^{2-}$ from 0 to $63 \mathrm{meq} \mathrm{L}^{-1}$ and $\mathrm{BO}_{3}{ }^{3-}$ from 0.2 to $1.25 \mathrm{mg} \mathrm{L}^{-1}$.

The mean values of each of $\mathrm{pH}, \mathrm{EC}$ and TDS were found to be higher in granitic formations whereas the mean of $\mathrm{Na}^{2+}, \mathrm{Ca}^{2+}$ and $\mathrm{Mg}^{2+}$ was higher in basaltic alluvial formation. The mean anionic concentration was similar in three geological formations, except for $\mathrm{SO}_{4}{ }^{2-}$ which was lower in gneissic terrains. The standard deviation (SD) was high for EC, TDS, $\mathrm{Na}^{+}, \mathrm{Ca}^{2+}$ and $\mathrm{Mg}^{2+}$ indicating dispersion of ionic concentration from the mean (Table 1). SD was low for $\mathrm{pH}, \mathrm{K}^{+}, \mathrm{Cl}^{-}, \mathrm{HCO}_{3}{ }^{-}$and $\mathrm{BO}_{3}{ }^{3-}$ indicating their limited variability. $\mathrm{Na}^{+}$constituted $29-43.5 \%$ of the ionic composition in groundwater of basaltic alluvium origin, $23-50 \%$ in granitic terrain and $17-59 \%$ in peninsular gneissic complex origin aquifers (Table 1). The variation in ionic content of water within the samples of geological region, as established by high SD, may be due to the differences in mineral makeup in aquifer material (Randall et al. 1996; Reddy and Kumar 2010). The ionic

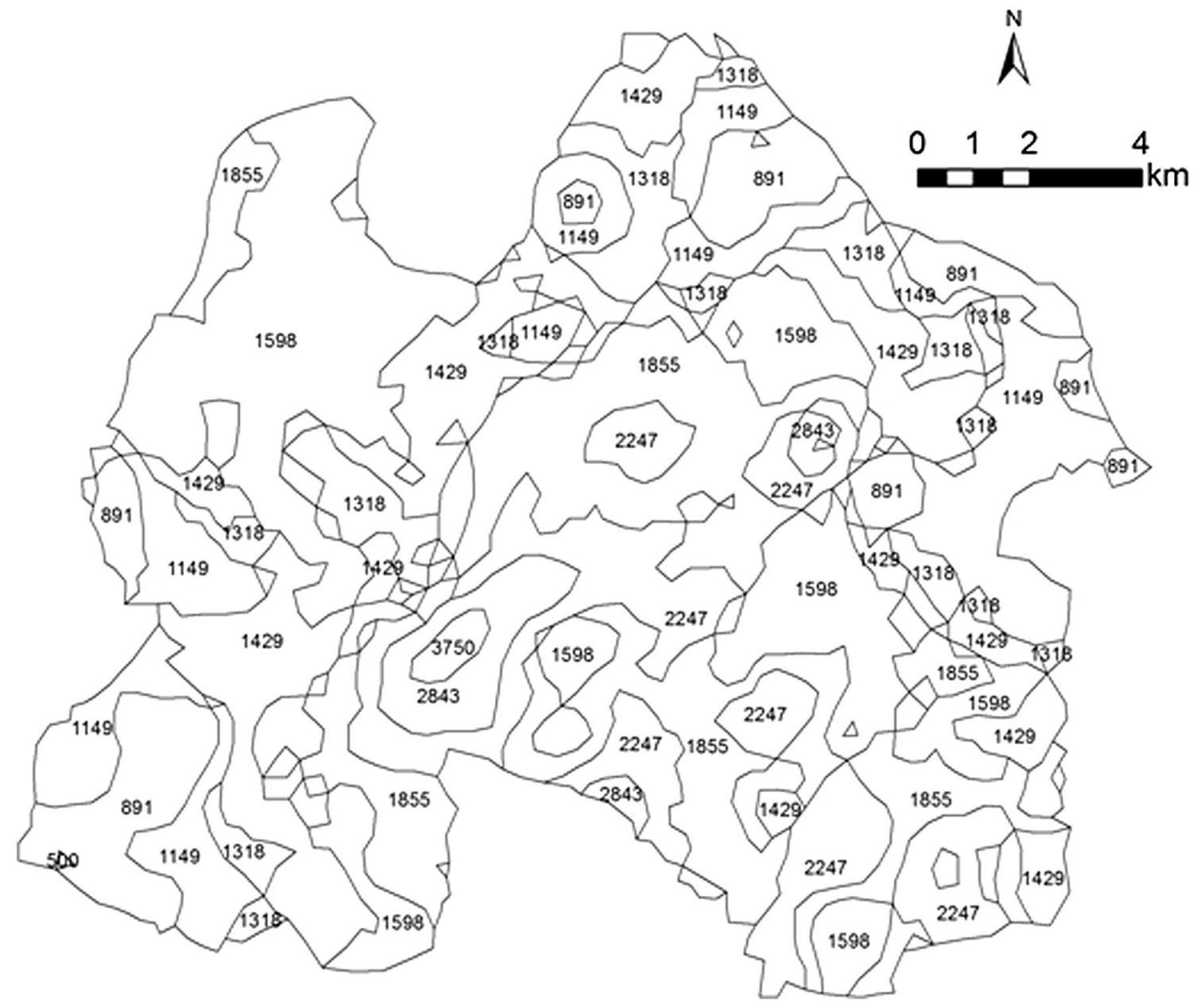

Fig. 2 Spatial distribution of EC $\left(\mu \mathrm{cm}^{-1}\right)$ in the study area 
sequence based on relative proportions was $\mathrm{Na}^{+}>$$\mathrm{Mg}^{2+}>\mathrm{Ca}^{2+}>\mathrm{SO}_{4}{ }^{2-}>\mathrm{HCO}_{3}{ }^{-}>\mathrm{Cl}^{-}>\mathrm{CO}_{3}{ }^{2-}>-$ $\mathrm{BO}_{3}{ }^{3-}>\mathrm{K}^{+}$. Higher content of $\mathrm{Ca}^{2+}$ and $\mathrm{Mg}^{2+}$ over $\mathrm{K}^{+}$ in the groundwater may be due to their mineralogical origin in the soils. During monsoon season, water percolates down to aquifer through soil and the weathered mantle gains $\mathrm{Ca}^{2+}$ and $\mathrm{Mg}^{2+}$. High $\mathrm{Na}^{+}$content may be attributed to weathering of silicate rocks containing sodium (e.g. feldspars) which was further enhanced by decreasing soil:water ratio due to high evaporative demand.

\section{Classification of groundwater}

The water type classification for the study area was done based on Piper diagram for dominant hydrochemical facies plotted on the cation, anion triangles and diamond matrix (Fig. 3). The samples were classified as $\mathrm{Na}-\mathrm{Mg}-\mathrm{HCO}_{3}$ type $(50 \%)$; $\mathrm{Ca}-\mathrm{Mg}-\mathrm{HCO}_{3}$ type (14\%); $\mathrm{Na}-\mathrm{Mg}-\mathrm{Ca}-\mathrm{SO}_{4}$ and $\mathrm{Mg}-$ $\mathrm{Na}-\mathrm{Ca}-\mathrm{SO}_{4}$ type (10\% each). The Na-dominated water was the result of interaction of recharging waters with the sodium feldspars $\left(\mathrm{NaAlSi}_{3} \mathrm{O}_{8}\right)$. The $\mathrm{Na}^{+}$ions in water were added by the weathering of rocks (Keesari et al. 2013). It can be inferred from Piper plots that the groundwater is of mixed type with multiple processes involved in its evolution which further strengthens the fact that the mineralogy of aquifer material played an important role in determining the water chemistry. The plots also suggest that among cations $\mathrm{Na}^{+}, \mathrm{Ca}^{2+}$ and $\mathrm{Mg}^{2+}$ and among anions $\mathrm{SO}_{4}{ }^{2-}$ and $\mathrm{Cl}^{-}$dominate the ionic composition of the groundwater.

\section{Hydrogeochemical processes}

\section{Silicate weathering}

The weathering processes occurring in the aquifer environment were studied by scatter diagrams of ions and ionic combinations. $\mathrm{Ca}^{2+}$ and $\mathrm{Mg}^{2+}$ were the dominant cations after $\mathrm{Na}^{+}$in groundwater of the study area. The study of $\mathrm{Ca}^{2+} / \mathrm{Mg}^{2+}$ ratio indicated that silicate weathering was one of the process involved in determining ionic chemistry of groundwater. The $\mathrm{Ca}^{2+} / \mathrm{Mg}^{2+}$ ratio of 1 indicated dissolution of dolomite and of more than 2 silicate mineral weathering (Reddy and Kumar 2010). The majority of the samples in different geological terrains in the study area had $\mathrm{Ca}^{2+/} \mathrm{Mg}^{2+}$ ratio less than 1 and between 1 and 2, indicating that dolomite and calcite dissolution contributed towards high $\mathrm{Ca}^{2+}$ and $\mathrm{Mg}^{2+}$ followed by silicate mineral dissolution. The scatter diagram of $\left(\mathrm{Ca}^{2+}+\mathrm{Mg}^{2+}\right)$ vs
Fig. 3 Piper trilinear diagram showing the major ionic composition of groundwater from the study area

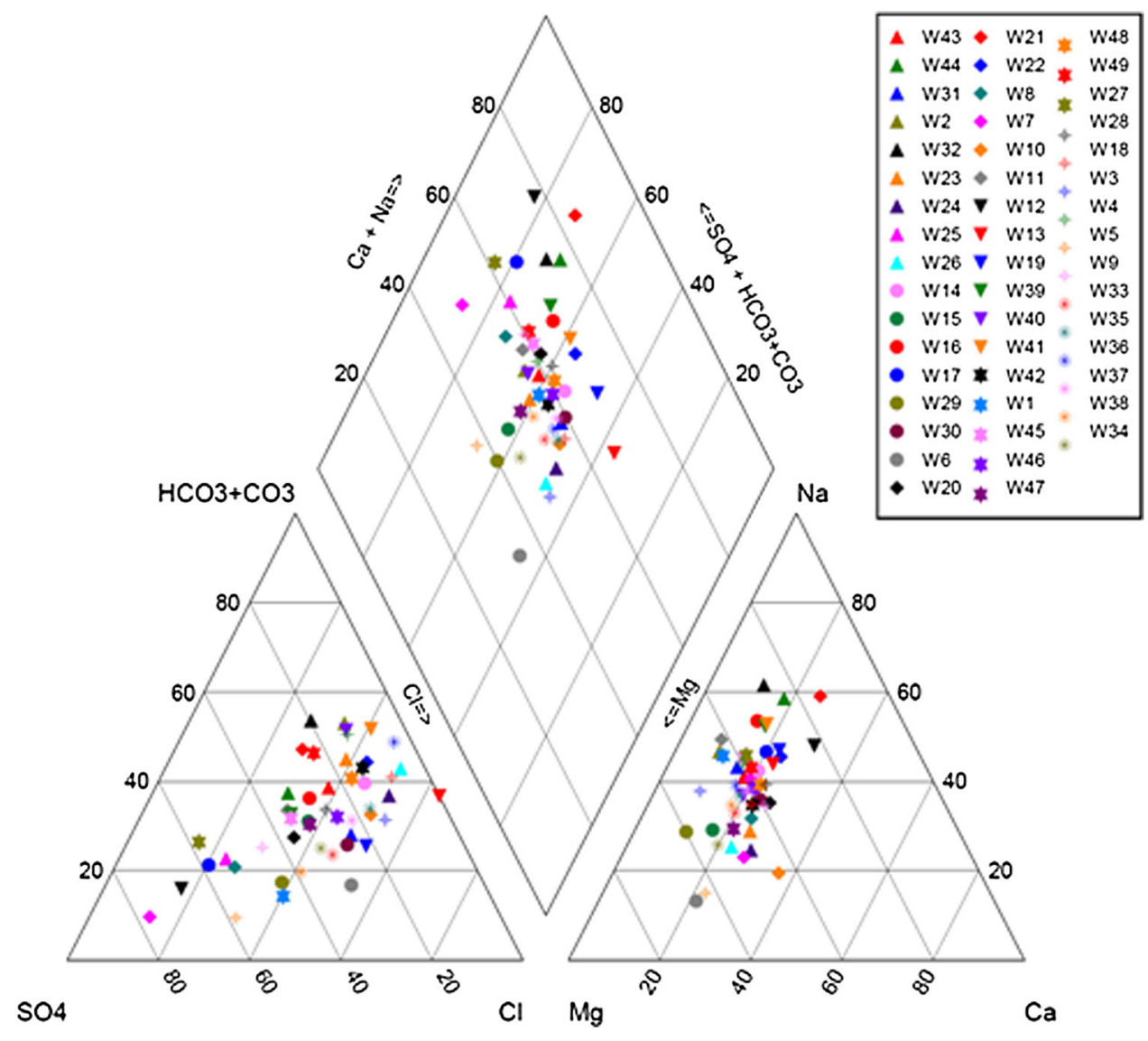



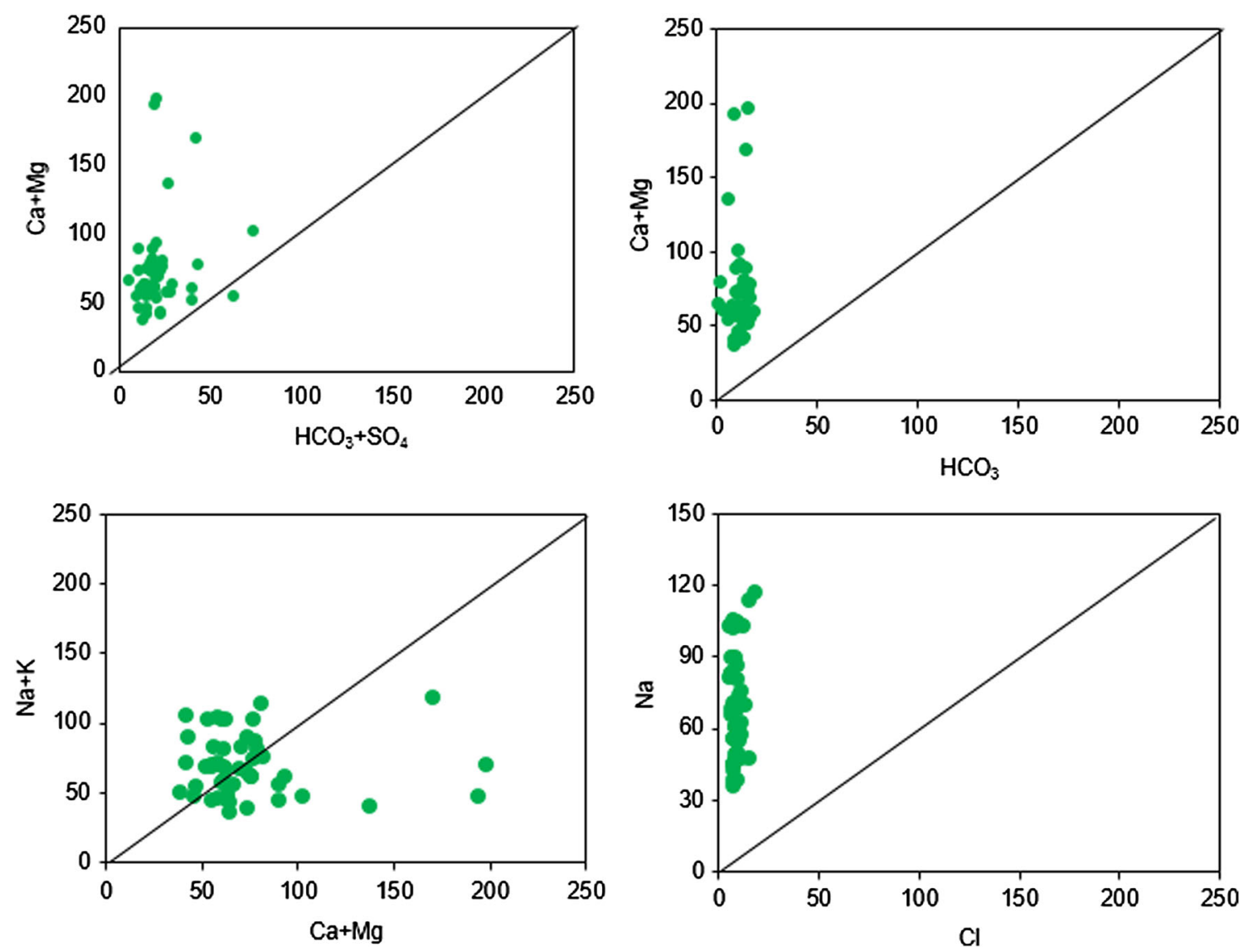

Fig. 4 a scatter plot of $\mathrm{Ca}^{2+}+\mathrm{Mg}^{2+}$ vs $\mathrm{HCO}_{3}{ }^{-}+\mathrm{SO}_{4}{ }^{2-}$; b scatter plot of $\mathrm{Ca}^{2+}+\mathrm{Mg}^{2+}$ vs $\mathrm{HCO}_{3}^{-}$; c scatter plot of $\mathrm{Ca}^{2+}+\mathrm{Mg}^{2+}$ vs $\mathrm{Na}^{+}+\mathrm{K}^{+}$; d scatter plot of $\mathrm{Na}^{+} \mathrm{vs} \mathrm{Cl}^{-}$

$\left(\mathrm{HCO}_{3}{ }^{-}+\mathrm{SO}_{4}{ }^{2-}\right)$ (Fig. 4a) showed that all samples fall above the equiline, indicating that dolomite dissolution was the primary process determining the chemistry of groundwater. In peninsular gneissic complex and granitic terrains, $\mathrm{Mg}^{2+}$ concentration was higher than $\mathrm{Ca}^{2+}$ which indicates the weathering of ferro-magnesian minerals (Datta and Tyagi 1996).

The high ratio of $\mathrm{Ca}^{2+}+\mathrm{Mg}^{2+} / \mathrm{HCO}_{3}{ }^{-}$indicated that $\mathrm{Ca}^{2+}$ and $\mathrm{Mg}^{2+}$ were added to the groundwater at a greater rate than $\mathrm{HCO}_{3}{ }^{-}$(Glover et al. 2012). In the scattered diagram $\left(\mathrm{Ca}^{2+}+\mathrm{Mg}^{2+}\right)$ vs $\left(\mathrm{HCO}_{3}{ }^{-}\right)$, all samples fall above the $1: 1$ equiline with excess $\mathrm{Ca}^{2+}$ and $\mathrm{Mg}^{2+}$ indicating the dominance of silicate weathering over carbonate weathering (Fig. 4b). The dominance of silicate weathering was also indicated by the scatter plot between $\left(\mathrm{Ca}^{2+}+\mathrm{Mg}^{2+}\right)$ vs $\left(\mathrm{Na}^{+}+\mathrm{K}^{+}\right)$as $55 \%$ samples plotted above the equiline (Fig. 4c). It is known that a ratio of $\mathrm{Mg}^{2+} /\left(\mathrm{Mg}^{2+}+\mathrm{Ca}^{2+}\right)$ greater than 0.5 indicates silicate weathering (Drever 1997), and $80 \%$ of the samples in this study area have $\mathrm{Mg}^{2+}$ / $\left(\mathrm{Mg}^{2+}+\mathrm{Ca}^{2+}\right)$ ratio of $>0.5$ which suggested that dissolution of silicate minerals significantly contributed towards high concentration of $\mathrm{Ca}^{2+}$ and $\mathrm{Mg}^{2+}$ to the groundwater in this area. $\mathrm{Na}^{+} / \mathrm{Cl}^{-}$ratio is indicative of whether halite dissolution or mineral weathering dominated in the aquifer system. The $\mathrm{Na}^{+} / \mathrm{Cl}^{-}$ratio of 1 indicates halite dissolution and $>1$ indicates silicate (plagioclase feldspar minerals) weathering process (Meybeck 1987). The $\mathrm{Na}^{+} / \mathrm{Cl}^{-}$molar ratio in the study area was $>1$ which indicated that $\mathrm{Na}^{+}$was released from silicate weathering which was evident from the scatter plot of $\mathrm{Na}$ vs $\mathrm{Cl}$ (Fig. 4d). The scatter plots of $\left(\mathrm{Na}^{+}+\mathrm{K}^{+}\right)$vs total cations (Fig. 5a) and $\left(\mathrm{Ca}^{2+}+\mathrm{Mg}^{2+}\right)$ vs total cations (Fig. 5b) and $\mathrm{Na}^{+}$vs $\mathrm{HCO}_{3}{ }^{-}$plot (Fig. 5c) showed that there is circumstantial evidence in favour of the dominance of silicate weathering (Rajmohan and Elango 2004). Gibbs plot (Gibbs 1970) for cations (Fig. 6) indicated that most of the samples were plotted in the rock dominance field and weathering of rocks was the major geochemical process influencing ionic chemistry as weathering of plagioclase feldspars (albite), pyroxenes and hornblende contributed to the high concentration of $\mathrm{Na}^{+}, \mathrm{Ca}^{2+}, \mathrm{Mg}^{2+}$ and $\mathrm{HCO}_{3}{ }^{-}$in groundwater (Senthilkumar and Elango 2013).

\section{Evaporation}

In arid and semi-arid regions evaporation may contribute as one of the processes influencing groundwater 

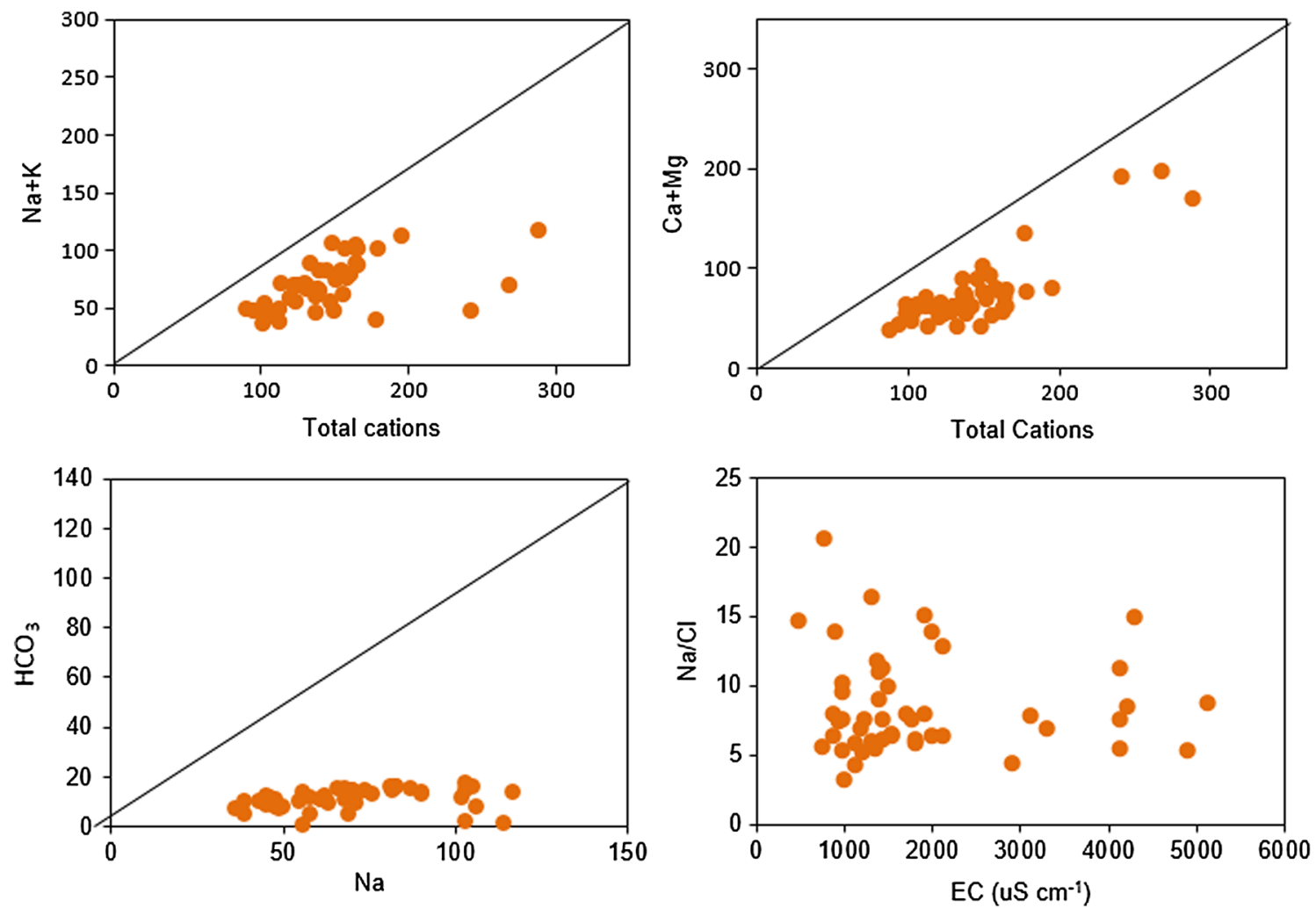

Fig. 5 a Scatter plot of $\mathrm{Na}^{+}+\mathrm{K}^{+}$vs Total cations; b scatter plot of $\mathrm{Ca}^{2+}+\mathrm{Mg}^{2+}$ vs Total cations; $\mathbf{c}$ scatter plot of $\mathrm{Na}^{+}$vs $\mathrm{HCO}_{3}{ }^{-}$; d scatter plot of $\mathrm{EC} \mathrm{vs} \mathrm{Na}^{+} / \mathrm{Cl}^{-}$

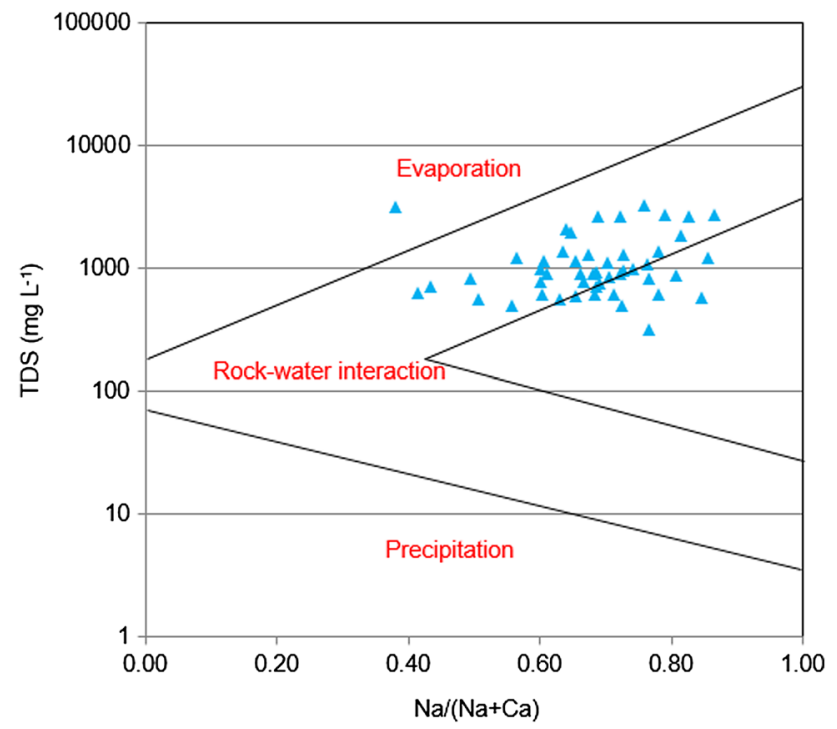

Fig. 6 Gibbs plot for cations

chemistry. The Gibbs plots were used to study the effect of precipitation, rock-water interaction and evaporation on chemistry of water. Gibbs plot for anions $\left(\mathrm{Cl}^{-} /\right.$ $\mathrm{Cl}^{-}+\mathrm{HCO}_{3}{ }^{-}$) indicated that $28 \%$ of the samples were plotted in the evaporation dominance region (Fig. 7). The study area with semi-arid climate experiences high

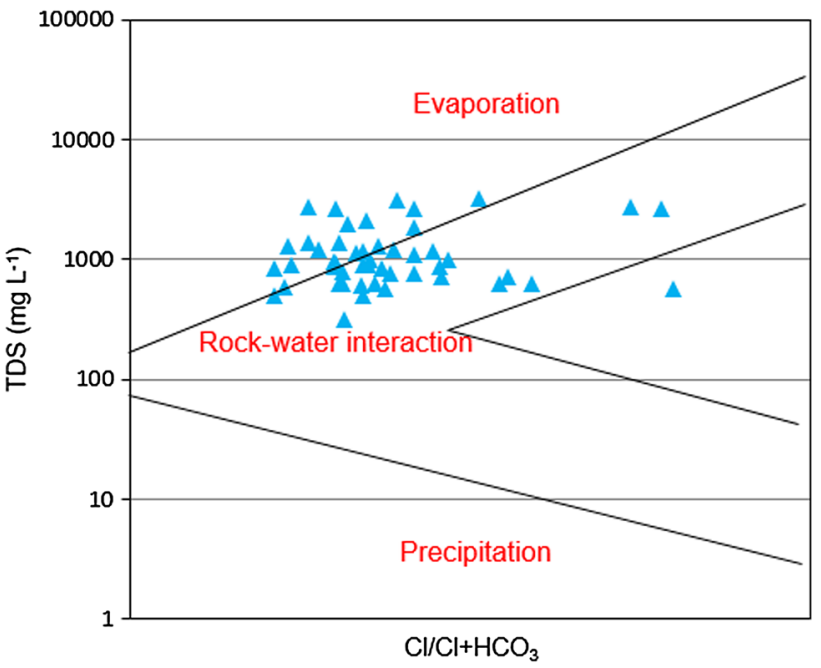

Fig. 7 Gibbs plot for anions

evaporation losses than precipitation (Pal et al. 2000). The influence of evaporation on groundwater is also supported by the scatter plot of EC vs $\mathrm{Na}^{+} / \mathrm{Cl}^{-}$. If evaporation is dominant process, $\mathrm{Na}^{+} / \mathrm{Cl}^{-}$ratio should be constant when EC increases (Jankowski and Acworth 1997). The EC vs $\mathrm{Na}^{+} / \mathrm{Cl}^{-}$scatter plot (Fig. 5d) showed that the $\mathrm{Na}^{+} / \mathrm{Cl}^{-}$ratio was not static and decreased with 
Table 2 Spearman Correlation for the variables in the study area

\begin{tabular}{|c|c|c|c|c|c|c|c|c|c|c|c|}
\hline & $\mathrm{pH}$ & $\begin{array}{l}\mathrm{EC} \\
\left(\mu \mathrm{scm}^{-1}\right)\end{array}$ & $\begin{array}{l}\mathrm{K}^{+} \\
\left(\text {meq } \mathrm{L}^{-1}\right)\end{array}$ & $\begin{array}{l}\mathrm{Na}^{+} \\
(\text {meq L L }\end{array}$ & $\begin{array}{l}\mathrm{Ca}^{2+} \\
\left(\mathrm{meq} \mathrm{L} \mathrm{L}^{-1}\right)\end{array}$ & $\begin{array}{l}\mathrm{Mg}^{2+} \\
\left(\mathrm{meq} \mathrm{L} \mathrm{L}^{-1}\right)\end{array}$ & $\begin{array}{l}\mathrm{Cl}^{-} \\
\left(\text {meq L }{ }^{-1}\right)\end{array}$ & $\begin{array}{l}\mathrm{CO}_{3}{ }^{2-} \\
\left(\mathrm{meq} \mathrm{L} \mathrm{L}^{-1}\right)\end{array}$ & $\begin{array}{l}\mathrm{HCO}_{3}^{-} \\
\left(\mathrm{meq} \mathrm{L} \mathrm{L}^{-1}\right)\end{array}$ & $\begin{array}{l}\mathrm{SO}_{4}{ }^{2-} \\
\left(\mathrm{meq} \mathrm{L}^{-1}\right)\end{array}$ & $\begin{array}{l}\mathrm{BO}_{3}{ }^{3-} \\
\left(\text { meq L }^{-1}\right)\end{array}$ \\
\hline $\mathrm{pH}$ & 1.000 & & & & & & & & & & \\
\hline $\mathrm{EC}\left(\mu \mathrm{s} \mathrm{cm}^{-1}\right)$ & 0.783 & 1.000 & & & & & & & & & \\
\hline $\mathrm{K}^{+}\left(\right.$meq L $\left.{ }^{-1}\right)$ & -0.194 & -0.172 & 1.000 & & & & & & & & \\
\hline $\mathrm{Na}^{+}\left(\right.$meq L $\left.{ }^{-1}\right)$ & 0.152 & 0.170 & -0.065 & 1.000 & & & & & & & \\
\hline $\mathrm{Ca}^{2+}\left(\mathrm{meq} \mathrm{L}^{-1}\right)$ & 0.061 & 0.056 & 0.263 & -0.090 & 1.000 & & & & & & \\
\hline $\mathrm{Mg}^{2+}\left(\right.$ meq L $\left.{ }^{-1}\right)$ & -0.036 & -0.079 & 0.557 & 0.035 & 0.568 & 1.000 & & & & & \\
\hline $\mathrm{Cl}^{-}\left(\right.$meq L $\left.{ }^{-1}\right)$ & 0.200 & 0.194 & 0.267 & 0.220 & 0.326 & 0.681 & 1.000 & & & & \\
\hline $\mathrm{CO}_{3}{ }^{2-}\left(\right.$ meq L $\left.\mathrm{L}^{-1}\right)$ & 0.436 & 0.430 & -0.081 & 0.330 & -0.256 & -0.067 & 0.177 & 1.000 & & & \\
\hline $\mathrm{HCO}_{3}{ }^{-}\left(\mathrm{meq} \mathrm{L}^{-1}\right)$ & -0.198 & -0.240 & -0.206 & 0.282 & 0.173 & -0.108 & -0.244 & -0.577 & 1.000 & & \\
\hline $\mathrm{SO}_{4}{ }^{2-}\left(\right.$ meq L $\left.{ }^{-1}\right)$ & -0.140 & -0.002 & 0.231 & 0.052 & 0.136 & 0.176 & 0.165 & -0.020 & -0.097 & 1.000 & \\
\hline $\mathrm{BO}_{3}{ }^{3-}\left(\right.$ meq L $\left.{ }^{-1}\right)$ & 0.291 & 0.218 & -0.242 & -0.005 & 0.354 & 0.093 & 0.167 & -0.074 & 0.039 & -0.338 & 1.000 \\
\hline
\end{tabular}

Table 3 Rotated component matrix of groundwater properties in the study area

\begin{tabular}{|c|c|c|c|c|c|}
\hline \multirow[t]{2}{*}{ Variable } & \multicolumn{5}{|c|}{ Component } \\
\hline & 1 & 2 & 3 & 4 & 5 \\
\hline $\mathrm{pH}$ & 0.021 & 0.100 & 0.870 & -0.172 & -0.146 \\
\hline $\mathrm{EC}$ & -0.003 & 0.095 & 0.901 & -0.166 & 0.024 \\
\hline $\mathrm{K}$ & 0.596 & -0.105 & -0.334 & -0.207 & 0.302 \\
\hline $\mathrm{Na}$ & 0.092 & 0.979 & 0.084 & 0.051 & 0.033 \\
\hline $\mathrm{Ca}$ & 0.699 & -0.219 & 0.220 & 0.479 & -0.032 \\
\hline $\mathrm{Mg}$ & 0.944 & -0.039 & -0.099 & -0.020 & 0.024 \\
\hline $\mathrm{Cl}$ & 0.770 & 0.187 & 0.169 & -0.216 & -0.032 \\
\hline $\mathrm{CO}_{3}{ }^{2-}$ & -0.033 & 0.356 & 0.376 & -0.742 & 0.037 \\
\hline $\mathrm{HCO}_{3}{ }^{-}$ & -0.142 & 0.301 & -0.174 & 0.863 & -0.053 \\
\hline $\mathrm{SO}_{4}^{2-}$ & 0.194 & 0.000 & 0.087 & 0.081 & 0.882 \\
\hline $\mathrm{BO}_{3}{ }^{3-}$ & 0.210 & -0.047 & 0.375 & 0.240 & -0.700 \\
\hline RSC & -0.951 & 0.234 & -0.027 & -0.099 & -0.009 \\
\hline
\end{tabular}

increase in EC because the transference number (related to velocity or conductance of ions in solution) of all ions increases with increase in EC compared to that of $\mathrm{Na}^{+}$ which is overshadowed by increase in transference number of all other ions (Glasstone 1968). Gibbs plot suggests that the rate of removal of groundwater being higher compared to its recharge, the concentration of certain ions was higher compared to others depending on their solubility product. Thus the effect of excessive use of groundwater coupled with semi-arid conditions may have an indelible effect on the degradation of water resources in this region.

\section{Ion exchange}

Ion exchange was one of the important processes responsible for concentration of ions in the groundwater. In the present study, reverse ion exchange was responsible for increased sodium concentration in gneissic complex terrain (Guo and Wang 2004) and the excess $\mathrm{Na}^{+}$over $\mathrm{Cl}^{-}$was a good indicator of reverse ion exchange process. This can be confirmed by chloro-alkaline index proposed by Schoeller (1977). Positive values (61\% samples) suggested that reverse ion exchange occurred in the groundwater. $\mathrm{Ca}^{2+}$ and $\mathrm{Mg}^{2+}$ exchange $\mathrm{Na}^{+}$from exchangeable sites on the aquifer minerals which increases the $\mathrm{Na}^{+}$concentration. The remaining 39\% samples with negative chloro-alkaline index indicated exchange between $\mathrm{Ca}^{2+}$ and/or $\mathrm{Mg}^{2+}$ in groundwater with $\mathrm{Na}^{+}$and/or $\mathrm{K}^{+}$in the aquifer mineral. The molar ratios of sodium to that of divalent cations $\mathrm{Ca}^{2+}$ and $\mathrm{Mg}^{2+}$ are indicative of the dominance of particular cation. The high ratio of $\mathrm{Na} /(\mathrm{Ca})^{1 / 2}$ and $\mathrm{Na} /(\mathrm{Ca}+\mathrm{Mg})^{1 / 2}$ also indicated (Table 1) that $\mathrm{Na}^{+}$concentration was higher than $\mathrm{Ca}^{2+}$ and $\mathrm{Mg}^{2+}$ in the groundwater. 
Fig. 8 a Surface salt encrustation; $\mathbf{b}$ wilted rice seedlings after irrigation with groundwater with high salt content
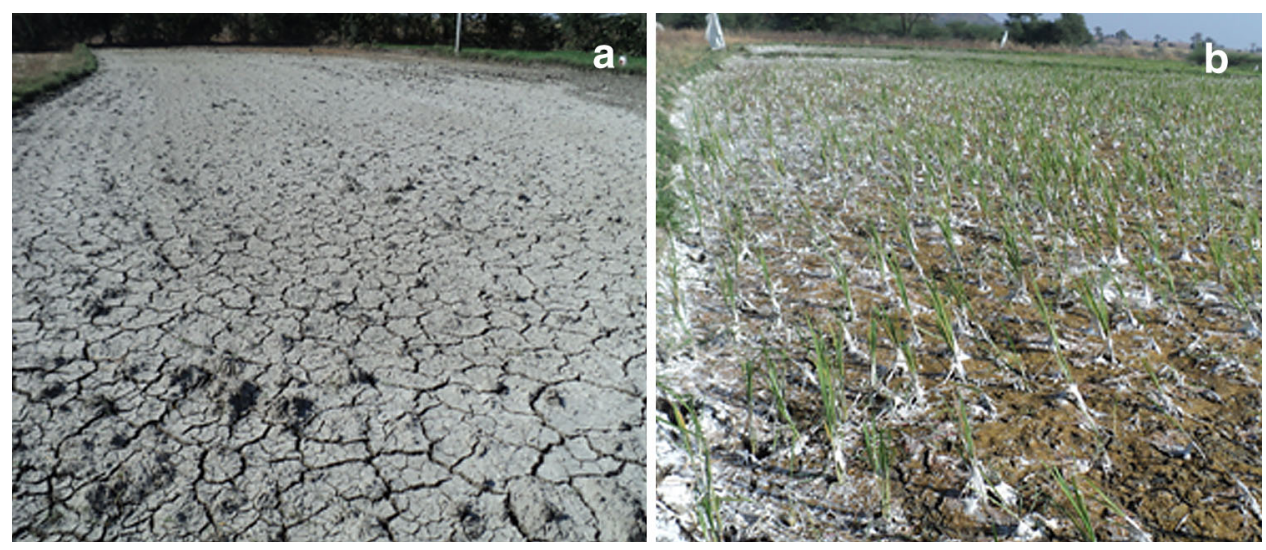

\section{Correlation matrix and factor analysis}

The spearman correlation matrix for 13 variables is shown in Table 2. The resultant matrix showed strong correlation between $\mathrm{pH}$ and EC. Likewise, strong negative correlation between $\mathrm{Ca}^{2+}, \mathrm{Mg}^{2+}$ and residual sodium carbonate (RSC) was evident. It also showed weak correlation of $\mathrm{pH}$ with other variables. The factor analysis resulted in five factors in a rotated component matrix accounting for $83.76 \%$ of the total variation in the hydrogeochemistry of the study area. The extracted factor results were applied to calculate the primary associated factors. Five factor variables (Table 3) with variable factor loadings explain variation in the groundwater chemistry. $\mathrm{Mg}^{2+}, \mathrm{Ca}^{2+}, \mathrm{Cl}^{-}$and $\mathrm{K}^{+}$have high positive factor loading in factor 1 which accounts for $26.48 \%$ of variance. $\mathrm{Na}^{+}, \mathrm{CO}_{3}{ }^{2-}, \mathrm{HCO}_{3}{ }^{-}$and $\mathrm{RSC}$ have high positive factor loadings in factor $2(16.89 \%$ variance). $\mathrm{pH}, \mathrm{EC}, \mathrm{HCO}_{3}{ }^{-}$and $\mathrm{BO}_{3}{ }^{3-}$ have high positive factor loadings in factor 3 (16.25\% variance). $\mathrm{HCO}_{3}{ }^{-}, \mathrm{Ca}^{2+}$ and $\mathrm{BO}_{3}{ }^{3-}$ have high positive factor loadings in factor 4 (13.46\% variance) and $\mathrm{SO}_{4}{ }^{2-}$ and $\mathrm{K}^{+}$have high positive factor loadings in factor 5 (10.68\% variance). $\mathrm{Na}^{+}, \mathrm{CO}_{3}{ }^{2-}$ and $\mathrm{HCO}_{3}{ }^{-}$have high positive factor loadings (factor 2) in rotated component matrix indicating that these ions were a combined result of silicate weathering and other processes in vogue. The high positive loadings for every variable in at least one of the component factors also indicates that rock-water interaction, ion exchange, silicate weathering and to a limited extent, evaporation, determine the groundwater chemistry in the study area.

\section{Irrigation suitability}

The safe $\mathrm{pH}$ range for irrigation water is $6.5-8.4$ (USSL 1954). However, in the study area $12 \%$ samples showed $\mathrm{pH}$ of more than 8.5 which may harm plant growth by inducing soil alkalinity and specific ion toxicity. Besides, most of the water samples were high in $\mathrm{Na}^{+}$and may develop secondary alkalinity on entry into the exchange complex of soils (more readily with low EC) when used for irrigation (Ray et al. 2000). This is more probable as the solubility of $\mathrm{Ca}^{2+}$ encounters a change of phase from a $\mathrm{pH} \geq 8.2$. According to USSL (1954) standards, the EC of the water samples varied from low to high and $14 \%$ have EC more than the threshold value ( $\left.4000 \mu \mathrm{S} \mathrm{cm}^{-1}\right)$ which caused salt injury to the plants due to secondary salinization which was evident from Fig. 8 a, b. The results showed that $20 \%$ of the groundwater samples have TDS more than $1500 \mathrm{mg} \mathrm{L}^{-1}$ and were classified as unsuitable for irrigation. The usual range of $\mathrm{Ca}^{2+}$ and $\mathrm{Mg}^{2+}$ in irrigation water is $0-20$ and 0-5 meq L ${ }^{-1}$, respectively (Ayers and Westcot 1985). In this study, $92 \%$ of water samples have $\mathrm{Ca}^{2+}$ more than $20 \mathrm{meq} \mathrm{L}{ }^{-1}$ and all the samples have $\mathrm{Mg}^{2+}$ above the maximum threshold value. According to Ayers and Westcot (1985), 92\% groundwater samples show moderate to high boron toxicity.

The results indicated that $94 \%$ of water samples have high sodium content, more than the usual range of 0-40 meq L ${ }^{-1}$ (Ayers and Westcot 1985). High percentage sodium in groundwater which is used for irrigation may stunt the plant growth and reduce soil permeability (Joshi et al. 2009). The soluble sodium percentage of groundwater varied from 19.74 to $71.54 \%$ and $17 \%$ of water samples are unsuitable for irrigation with SSP $>60 \%$. This may lead to high sodium adsorption ratio in irrigated soils and reduce the hydraulic conductivity of soil. Moreover, the groundwater containing high proportions of sodium will enhance the exchange reaction between water and soil for alkaline earth metals, affecting the soil permeability and the texture which makes the soil hard to plough and unsuitable for seedling emergence (Keesari et al. 2013).

The magnesium hazard in the groundwater samples ranged between 26.42 to 76.09 and $80 \%$ of water samples were above the acceptable limit of 50\% (Ayers and Westcot 1985). Generally, calcium and magnesium maintain a state of equilibrium in most waters. High level of magnesium deteriorates soil structure, particularly when waters are sodium dominated, and enhances the hazardous 
effect of $\mathrm{Na}$ in irrigated soils and induces hardness in soils. The soils of the study area are red and black soil associations dominated by smectitic clays which swell and shrink during wet and dry seasons, respectively. There are reports of impairment of hydraulic properties due to high exchangeable $\mathrm{Na}^{+}$and $\mathrm{Mg}^{2+}$ in the exchange complex of the clays (Balpande et al. 1996; Chandran et al. 2014) and precipitation of $\mathrm{Ca}^{2+}$ as $\mathrm{CaCO}_{3}$ in the dry season due to high evaporation demand. It leads to decrease in partial pressure of carbon dioxide which induces sodicity in the soils and this gets aggravated if irrigation water with high sodium is used for irrigation. As per USSL (1954) guidelines, $70 \%$ groundwater samples were classified as C3S3 (high salinity hazard) and $\mathrm{C} 3 \mathrm{~S} 2$ (medium to high sodium hazard), $16 \%$ as $\mathrm{C} 4 \mathrm{~S} 3$ and $\mathrm{C} 3 \mathrm{~S} 4$ (high salinity and sodium hazard) and $10 \%$ as C4S4 (high salinity and sodium hazard) which could be attributed to the presence of $\mathrm{Na}$ dominant minerals in the groundwater aquifer material. Padekar et al. (2014) also reported high salinity and alkalinity hazard in irrigation water from semi-arid part of eastern Maharashtra.

Since the calcium and magnesium content was proportionately too high, the effect of carbonate and bicarbonate in terms of RSC index was low $(-89$ to -5$)$ because of the neutralising effect of other acid anions $\left(\mathrm{Cl}^{-}, \mathrm{SO}_{4}{ }^{2-}\right)$ rendering the $\mathrm{pH}$ relatively lower (Tables 1 and 2). Potential salinity is an indicator of ability of water to cause salinity in soils and the suitability of water for safe use in different textured soils. Potential salinity ranged between 7 and $40 \mathrm{meq} \mathrm{L}^{-1}$ and groundwater was unsuitable for irrigation in fine-textured soils ( $\mathrm{PS}>3$ ). The Kelly's ratio varied from 0.25 to 2.53 in the study area. Kelly's ratio more than 1 is not suitable for irrigation and $49 \%$ of water samples were not suitable for irrigation. The chemical or ionic composition of groundwater influences the soil permeability based on the soil type. The results of the present study showed that the permeability index varied from 23 to 77 and suggest that all the water samples fall in the category of class V $(>20)$ and were not safe for irrigation since it will affect the soil permeability upon long-term use.

\section{Conclusions}

The groundwater of the study area was slightly alkaline and dominated by $\mathrm{Na}^{+}, \mathrm{Ca}^{2+}$ and $\mathrm{Mg}^{2+}$. The groundwater chemistry was influenced by silicate weathering, reverse ion exchange and rock-water interaction. It can be inferred from various geochemical and statistical results that the groundwater is of mixed type with multiple processes involved in its evolution. Mineralogy of the aquifer material played an important role in determining the water chemistry with high values of $\mathrm{Na}^{+}$to divalent cation ratios which may pose threat to the cultivated crops by inducing specific ion toxicity and osmotic stress. Since the majority of the water samples were classified as highly saline, use of groundwater blended with freshwater or surface water for irrigation should be an option to minimise the potential of soil salinity and salt injury to the plants. In-spite of the fact that the $\mathrm{pH}$ of the groundwater was not exceedingly high, the dominance of $\mathrm{Na}$ in the groundwater may have indelible effect on the soils and crops if used for irrigation for a longer time by impeding the hydraulic properties of soils. Hence, the study of hydrogeological processes and water chemistry will be highly beneficial for using these water for irrigation and for the sake of posterity.

\section{Compliance with ethical standards}

\section{Conflict of interest None.}

Open Access This article is distributed under the terms of the Creative Commons Attribution 4.0 International License (http:// creativecommons.org/licenses/by/4.0/), which permits unrestricted use, distribution, and reproduction in any medium, provided you give appropriate credit to the original author(s) and the source, provide a link to the Creative Commons license, and indicate if changes were made.

\section{References}

Aghazadeh N, Mogaddam AA (2011) Investigation of hydrochemical characteristics of groundwater in the Harzandat aquifer, Northwest of Iran. Environ Monit Assess 176:183-195

APHA (2005) Standard methods for examination of water and wastewater, 21st edn. American Public Health Association, Washington DC

Ayers RS, Westcot DW (1985) Water quality for agriculture: in FAO irrigation and drainage paper 29

Balakrishnan S, Hanson GN, Rajamani V (1990) Pb and Nd isotope constrains on the origin of high-Mg and tholeiiticamphiboliths Kolar Schist Belt South India. Contrib Miner Petrol 107:279-292

Balakrishnan S, Rajamani V, Hanson GN (1999) U-Pb ages for zircon and titanite from the Ramagiri area Southern India: evidence for accretionary origin of the eastern Dharwar craton during the late. Archaean J Geol 107:69-86

Balpande SS, Deshpande SB, Pal DK (1996) Factors and processes of soil degradation in Vertisols of the Puma valley Maharashtra India. Land Degrad Dev 7:313-324

Belkhiri L, Boudoukha A, Mouni L (2010) Groundwater quality and its suitability for drinking and agricultural use in Ain Azel plain Alregia. J Geogr Reg Plan 3(6):151-157

Central Ground Water Board (1975) Ground water resources of South India. Ministry of Water Resources, Govt. of India, New Delhi

Central Ground Water Board (2009) Dynamic ground water resources of India. Ministry of Water Resources, Govt. of India, New Delhi

Central Ground Water Board (2012) Aquifer systems in India. Ministry of Water Resources, Govt. of India, Faridabad

Central Ground Water Board (2013) Groundwater Brochure. Mahabubnagar district, Andhra Pradesh, Ministry of Water Resources, Govt. of India

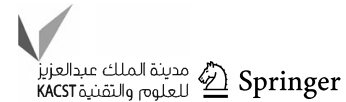


Central Ground Water Board (2015) Ground water year book 2014-15. Ministry of Water Resources, Govt. of India, Faridabad

Chandra S, Nagaiah E, Reddy DV, Ananda Rao V, Ahmed S (2012) Exploring deep potential aquifer in water scarce crystalline rocks. J Earth Syst Sci 121(6):1455-1468

Chandran P, Ray SK, Bhattacharyya T, Tiwary P, Sarkar D, Pal DK, Mandal C, Nimkar AM, Raja P, Maurya UK, Anantwar SG, Karthikeyan K, Dongate VT (2014) Calcareousness and subsoil sodicity in ferruginous alfisols of Southern India : an evidence of climate shift. Clay Res 32(2):114-126

Datta PS, Tyagi SK (1996) Major ion chemistry of groundwater in Delhi area; chemical weathering processes and groundwater regime. J Geol Soc India 47:179-188

Doneen LD (1964) Notes on water quality in agriculture Published as a water science and engineering paper 4001. Department of Water Science and Engineering University of California

Drever JI (1997) The geochemistry of natural waters: surface and groundwater environments. Prentice-Hall, New Jersey, p 436

Elango L, Kannan R, Senthil Kumar M (2003) Major ion chemistry and identification of hydrogeochemical processes of groundwater in a part of Kanceepuram district, Tamil Nadu, India. J Environ Geosci 10:157-166

Gibbs RJ (1970) Mechanisms controlling worlds water chemistry. Science 170:1088-1090

Glasstone S (1968) Text book of physical chemistry. Springer, Berlin, p 1320

Glover ET, Akiti TT, Osae S (2012) Major ion chemistry and identification of geochemical processes of groundwater in the Accra Plains. Geoscience 50:10279-10288

Guo H, Wang Y (2004) Hydrogeochemical processes in shallow quaternary aquifers from the northern part of the Datong Basin China. Appl Geochem 19(1):19-27

Gupta SK, IC Gupta (1987) Management of saline soils and water. Oxford and IBH Publication Coy New Delhi India, pp 399

Hammett KM (1992) Physical processes salinity characteristics and potential salinity changes due to freshwater withdrawals in the Tidal Myakka River Florida US Geological Survey WaterResources Investigations Report 90-4054

Hem JD (1991) Study and interpretation of the chemical characteristics of natural water. US Geol Surv Water Supply Paper, 3rd edn. Scientific, Jodhpur

India Meteorological Department (2015) IMD Annual Report 2014. http://www.imdgovin/doc/report2014pdf

Jankowski J, Acworth RI (1997) Impact of debris-flow deposits on hydrogeochemical processes and the development of dryland salinity in the Yass river catchment New South Wales Australia. Hydrogeol J 5(4):71-88

Joshi DM, Kumar A, Agrawal N (2009) Assessment of the irrigation water quality of River Ganga in Haridwar District India. Rasayan J Chem 2(2):285-292

Keesari T, Kulkarni UP, Deodhar A, Ramanjaneyulu PS, Sanjukta AK, Saravana Kumar U (2013) Geochemical characterization of groundwater in an arid region in India. Environ Earth Sci 71:4869-4888

Kelly WP (1963) Use of saline irrigation water. Soil Sci 95(4):355-391

Krogstad EJ, Hanson GN, Rajamani V (1991) U-Pb ages of zircon and sphene for two gneiss terranes adjacent to the Kolar Schist Belt South India: evidence for separate crustal evolution histories. J Geol 99:801-816

Kumar NK, Reddy AGS, Reddy RM, Srinivas Varma K (2009) Preliminary investigation of groundwater quality in Hyderabad City Andhra Pradesh India. Int J Chem Sci 7(1):59-70

Meybeck M (1987) Global chemical weathering of surficial rocks estimated from river dissolved loads. Am J Sci 287:401-428
Moller P, Rosenthal E, Geyer S, Guttman J, Dulski PM, Rybakov M et al (2007) Hydrochemical processes in the lower Jordan valley and in the Dead Sea area. Chem Geol 239:27-49

Nageswara Rao VP, Appa Rao S, Subba Rao N (2015) Geochemical evolution of groundwater in the western delta region of River Godavari, Andhra Pradesh. Appl Water Sci. doi:10.1007/s13201015-0294-y

Obiefuna GI, Sheriff A (2011) Assessment of Shallow Ground Water Quality of PindigaGombe Area Yola Area NE Nigeria for Irrigation and Domestic Purposes. Res J Environ Earth Sci 3(2):131-141

Padekar DG, Bhattacharyya T, Deshmukh PD, Ray SK, Chandran P, Tiwary $P$ (2014) Is irrigation water causing degradation in black soils? Curr Sci 106(11):1487-1489

Pal DK, Dasog GS, Vadivelu S, Ahuja RL, Bhattacharyya T (2000) Secondary calcium carbonate in soils of arid and semi-arid regions of India. In: Lal R, Kimble JM, Eswaran H, Stewart BA (eds) Global climate change and pedogenic carbonates. Lewis Publishers, Boca Raton, pp 149-185

Perrin J, Ferrant S, Massuel S, Dewandel B, Marechal JC, Aulong S, Shmed S (2012) Assessing water availability in a semi-arid watershed of southern India using a semi-distributed model. J Hydrol 460-461:143-155

Pophare MA, Dewalkar SM (2007) Groundwater quality in eastern and southeastern parts of Rajura Teshil Chendrapur district Maharashtra. Gondwana Geol Mag 11:119-129

Raghunath IM (1987) Groundwater, 2nd edn. Wiley, New Delhi

Rajesh R, Brindha K, Murugan R, Elango L (2012) Influence of hydrochemical processes on temporal changes in groundwater quality in a part of Nalgonda district, Andhra Pradesh. Environ Earth Sci 65(4):1203-1213

Rajmohan N, Elango L (2004) Identification and evolution of hydrogeochemical processes in an area of the Palar and Cheyyar river basin Southern India. Environ Geol 46:47-61

Raju CS, Goud PVP (1990) Quality characterisation of groundwater in Koilsagar project area, Mahabubnagar district, Andhra Pradesh district, India. Environ Geol Water Sci 16(2):121-128

Randall MG, Trivedi DP, Graham J, Small JS, Hughes C (1996) Mineralogical characterization of sediments at the Drigg low level radioactive waste disposal site and the influence on groundwater chemistry (c) 1995-2009 Warrendale: Materials Research Society

Ray SK, Gajbhiye KS, Challa O, Prasad J, Singh SR, Anantwar SG, Gaikawad MS, Padihar SK (2000) Systematic soil survey to identify potential sodicity areas in parts of Tawa Command, Madhya Pradesh. J Indian Soc Soil Sci 48(2):346-351

Reddy IP (2013) Hydrogeochemistry of groundwater of Rangapur, Mahabubnagar district, Andhra Pradesh, India. J Appl Chem 15(3):361-371

Reddy AG, Kumar KN (2010) Identification of the hydrogeochemical processes in groundwater using major Ion chemistry; A case study in Penna-Chitravathi river basins in southern India. Environ Monit Assess 170(1-4):365-382

Reddy KR, Patode RS (2013) Assessment of groundwater quality-a case study in Kondapur Mandal, Medak district, Andhra Pradesh. Current World Environ 8(2):267-273

Rengaraj S (1996) Ground water quality in Suburban regions of Madras City. Pollut Res 15(4):325-328

Satyanarayanan M, Balaram V, Hussain MSA, Jemail I, Mara Rao TG, Mathur R, Dasaram B, Ramesh SL (2007) Assessment of groundwater quality in structurally deformed granitic terrain in Hyderabad India. Environ Monit Assess 131:117-127

Schoeller H (1977) Geochemistry of groundwater In Groundwater studies - an international guide for research and practice $(\mathrm{Ch}$ 15 pp 1-18) Paris: UNESCO

Selvakumar S, Ramkumar K, Chandrasekar N, Magesh NS, Kaliraj S (2014) Groundwater quality and its suitability for drinking and 
irrigational use in the southern Tiruchirapalli district, Tamil Nadu, India. Appl Water Sci. doi:10.1007/s13201-014-0256-9

Senthilkumar M, Elango L (2013) Geochemical processes controlling the groundwater quality in lower Palar river basin southern India. J Earth Syst Sci 122(2):419-432

Sharma RS (2009) Cratons and fold belts of India. Lect Notes Earth Sci 127:41. doi:10.1007/978-3-642-01459-8_2

Singh KP, Malik A, Mohan D, Singh VK, Sinha S (2006) Evaluation of Groundwater Quality in Northern Indo-Gangetic Alluvium Region. Environ Monit Assess 112:211-230

Soil Survey Staff (2003) Keys to soil taxonomy, 9th edn. Natural Resources Conservation Service, USDA, Washington, DC, pp 332

Srinivas Y, Hudson OD, Raj AS, Chandrasekar N (2013) Evaluation of groundwater quality in and around Nagarcoil town, Tamil Nadu, India: an integrated geochemical and GIS approach. Appl Water Sci 3:631-651

Subbarao N (2006) Seasonal variation of groundwater quality in a part of Guntur district, AP, India. Environ Geol 49:413-429

Subramani T, Rajmohan N, Elango L (2010) Groundwater geochemistry and identification of hydrogeochemical processes in a hard rock region Southern India. Environ Monit Assess 162:123-137
Suresh T, Kottureshwara NM (2009) Assessment of Groundwater Quality of Borewells Water of Hospet Taluka Region, Karnataka, India. Rasayan J Chem 2(1):221-233

Todd DK (1995) Groundwater hydrology, 3rd edn. Wiley, New York United States Salinity Laboratory Staff (1954) Diagnosis and Improvement of Saline and Alkali Soils Department of Agriculture. US Handbook 60

Vasu D, Singh SK, Tiwary P, Chandran P, Ray SK, Duraisami VP (2016) Pedogenic processes and soil - landform relationships for identification of yield limiting properties. Soil Res. doi:10.1071/ SR16111

Yadagiri K, Sundaraiah R, Sateesh P (2015) Assessing Groundwater Quality and its Suitability for Irrigation purpose in Kothur area, Mahabubnagar District, Telangana State, India. Indian J Appl Res 5(1):222-225

Zaporozec A (1972) Graphical interpretation of water quality data. Groundwater 10(2):32-43 